\title{
CRISIS MANAGEMENT OF LOCAL GOVERNMENT PUBLIC RELATION \\ (CASE STUDY ON IMAGE RECOVERY OF LOCAL GOVERNMENT KARAWANG REGENCY POST CORRUPTION CASE OF THE REGENT OF 2014)
}

\author{
Laelatul Pathia \\ Politeknik Negeri Media Kreatif Jakarta \\ E-mail: laylapathia@gmail.com
}

\begin{abstract}
Negative issues the arise in public become one determinant of the continuity of an institution. Instituions will gain more value if they can manage the issues into opportunities, but it can also be a threat if they can not prevent from the onset of crisis symptoms. Post operation catching hands conducted KPK to the head of the region, Ade Swara, and wife, Mrs. Nurlatifah in 2014 experienced a crisis of confidence from the community of Kabupaten Karawang. This study will use the management crisis Rhenald Kasali's, agenda building strategy, dan media relations activities, and describe how the onset of this crisis emerged, the factors causing, and the anatomy of crisis. Prevention of the crisis should be sought so that the institution is able to restore the trust of the community. The appoinment of Mrs. Cellica as Acting Officer of the Regent has been one of the efforts to restore the crisis, because the institution has regained the leadership capable of providing policies for the institutions existance. The results showed that the crisis that occured in Karawang regency is a type of smoldering crisis, where the crisis is not common in the institution. In the process of disseminating information, $P R$ do some media relations activities so that people get the informations related to the case. In addition, the researches also describe the pattern of institutions conducted on the media.
\end{abstract}

Keyword: Ade Swara, agenda building strategy, anatomi krisis, media relations, smoldering crisis.

MANAJEMEN KRISIS HUMAS PEMERINTAH DAERAH

\section{(STUDI KASUS PEMULIHAN CITRA PEMERINTAH DAERAH KABUPATEN KARAWANG PASCA KASUS KORUPSI KEPALA DAERAH TAHUN 2014)}

\begin{abstract}
ABSTRAK Isu-isu negatif yang muncul di masyarakat menjadi salah satu penentu keberlangsungan sebuah lembaga. Lembaga akan mendapatkan nilai tambah jika bisa mengelola isu tersebut menjadi peluang, tetapi juga bisa menjadi sebuah ancaman jika tak bisa mencegah sejak awal mula gejala krisis muncul. Kabupaten Karawang pasca Operasi Tangkap Tangan (OTT) yang dilakukan KPK kepada Kepala Daerah, Ade Swara, dan istri, Ibu Nurlatifah di tahun 2014 mengalami krisis kepercayaan dari masyarakat. Penelitian ini menggunakan teori manajemen krisis Rhenald Kasali, strategi agenda building, dan kegiatan-kegiatan media relations yang dilakukan Humas Kabupaten Karawang pada saat krisis, bagaimana awal mula krisis ini muncul, faktor-faktor penyebab, dan anatomi krisis yang terlihat sebelum krisis ini terjadi. Pencegahan krisis tersebut harus diupayakan sehingga pihak lembaga mampu mengembalikan kembali kepercayaan masyarakat. Pengangkatan Ibu Cellica sebagai Pelaksana Tugas (Plt) Bupati menjadi salah satu upaya untuk mengembalikan krisis, karena pihak lembaga memiliki kembali pimpinan yang mampu membrikan kebijakan-kebijakan demi eksistensi lembaga.Hasil penelitian menunjukan bahwa krisis yang terjadi di Kabupaten Karawang
\end{abstract}


adalah jenis smoldering crisis, dimana krisis tersebut tidak biasa terjadi di dalam lembaga. Dalam proses penyebaran informasi, Humas melakukan beberapa kegiatan media relations sehingga masyarakat mendapatkan perkembangan informasi terkait kasus tersebut. Selain itu, peneliti juga mendeskripsikan pola yang dilakukan lembaga.

Kata kunci: : Ade Swara, anatomi krisis, media relations, smoldering crisis, strategi agenda building 
Publipreneur Polimedia: Jurnal Ilmiah Jurusan Penerbitan Politeknik Negeri Media Kreatif Vol. 7, No. 1, July 2019

PENDAHULUAN

Lembaga

pemerintahan

merupakan lembaga sosial dari identitas yang dimiliki suatu daerah sebagai ciri bermartabat-tidaknya kehidupan masyarakat di daerah tersebut. Identitas yang dimiliki ini merupakan perwujudan dan hasil pencapaian dari kinerja yang selama ini dilakukan oleh pemerintah melalui pelaksanaan program-program kerja. Bungin (2006: 48) mendefinisikan lembaga (pranata) sosial merupakan sekumpulan tata aturan yang mengatur interaksi dan proses-proses sosial di dalam masyarakat, yang memungkinkan setiap struktur dan fungsi serta harapanharapan setiap anggota dalam masyarakat dapat berjalan dan memenuhi harapan sebagaimana yang disepakati bersama.

Program kerja tersebut menjadi bagian dari pertanggungjawaban yang harus dilaksanakan pemerintah atas kepercayaan yang diberikan masyarakat, dan amanat yang harus dijalankan oleh wakil rakyat, sehingga menjadi kontribusi selama masa jabatannya berlangsung.

Kepala pemerintah atau Bupati Kabupaten Karawang periode 2010-2015, H. Ade Swara merupakan salah satu pemimpin yang kepemimpinannya tidak berjalan mulus. Bupati yang terpilih dari hasil Pemilukada Kabupaten Karawang tahun 2010 ini, resmi dilantik bersama wakilnya, dr. Cellica Nurachadiana, yang menggantikan $H$. Dadang $S$. Muchtar dan Hj. Eli Amalia Priatna yang telah habis masa jabatannya.
Di tengah kepemimpinannya, pada Juli 2014, Bupati Karawang Ade Swara dijemput Komisi Pemberantasan Korupsi (KPK) atas dugaan izin penerbitan Surat Permohonan Pemanfaatan Tata Ruang (SPPR) yang dilakukan oleh Bupati Karawang Ade Swara, dan istrinya $\mathrm{Hj}$. Nurlatifah. Setelah proses pemeriksaan beberapa pihak seperti Bappeda Samsuri, Kabid Prasarana dan Tata Ruang Dindin Rachmady, dan Kasubidnya Puguh, Bupati Ade Swara, dan istrinya ditetapkan sebagai tersangka pada Jumat, 18 Juli 2014. Bupati Ade Swara dan istri, Hj. Nurlatifah dijerat menjadi tahanan lantaran di duga memeras PT Tatar Kertabumi sebanyak Rp. 5.000.000.000. PT Tatar Kertabumi merupakan anak perusahaan PT Agung Podomoro Land, yang baru saja diakuisisi APL melalui PT Pesona Gerbang Karawang senilai Rp 61.000.000.000. Perusahaan ini akan mengembangkan superblock mini di Kabupaten Karawang di atas lahan seluas 5,5 hektare.

Akibat perbuatan tersebut, Bupati Ade Swara, dan istri Hj. Nurlatifah disangkakan telah melanggar Pasal 12 e atau Pasal 23 Undang-Undang Nomor 31 Tahun 1999 sebagaimana telah diubah dengan Undang-Undang Nomor 20 Tahun 2001 jo Pasal 421 jo Pasal 55 KUHP, yang mengatur mengenai penyelenggara negara yang dengan menguntungkan diri sendiri, atau orang lain secara melawan hukum atau dengan menyalahgunakan kekuasaannya memaksa seseorang memberikan sesuatu, membayar untuk mengerjakan 
sesuatu bagi dirinya sendiri. Pasal ini mengancam para pidana dengan maksimal 20 tahun penjara dan denda paling banyak 1 miliar rupiah (Harian Radar Karawang, edisi 23 Juli 2014).

Setelah melalui beberapa pemeriksaan pihak terkait dan tujuh kali proses persidangan, pada tanggal 15 April 2015, Ketua Majelis Hakin Djoko Irianto di Pengadilan Tinggi Tindak Pidana Korupsi (Tipikor) Bandung, memvonis Bapak Ade Swara dengan hukuman penjara enam tahun, dan sang istri, Ibu Nurlatifah lima tahun. Keduanya secara sah dan meyakinkan melakukan korupsi dengan menerima suap, sebagaimana pasal 11 Undang Undang Tipikor, juga dijerat dengan pasal Tindak Pidana Pencucian Uang (TPPU). Mereka juga dibebani denda sebesar Rp 400 juta subsider 4 bulan penjara, sementara Nurlatifah didenda Rp 300 juta subsider 3 bulan penjara (Harian Radar Karawang, edisi 15 April 2015).

Ditahannya Bupati Ade Swara, dan istri $\mathrm{Hj}$. Nurlatifah menimbulkan kekecewaan masyarakat Kabupaten Karawang terhadap lembaga pemerintahan beserta jajarannya, sehingga mengakibatkan krisis kepercayaan. Meskipun demikian, program kerja dan kinerja pemerintahan harus tetap berjalan tertib dan stabil, sehingga membutuhkan pemimpin yang dapat menangani kinerja pemerintahan daerah Kabupaten Karawang. Setelah menunggu proses sejak penangkapan Bupati Ade Swara oleh KPK, pada tanggal 23 Desember 2014, akhirnya wakil Bupati, Ibu Cellica Nurachadiana diangkat menjadi Pejabat Pelaksana Tugas (Plt) Bupati Karawang. Diangkatnya Cellica Nurachadiana sebagai Plt Bupati merupakan tanggung jawab besar sebagai Plt, karena selain meneruskan tugas dan program kerja yang belum selesai dari Bupati sebelumnya, Cellica juga memiliki tugas penting yaitu memulihkan kembali citra pejabat daerah dan mengembalikan kembali kepercayaan masyarakat.

Pemulihan krisis ini harus diupayakan oleh Bagian Hubungan Masyarakat (Humas) Kabupaten Karawang agar isu-isu negatif dari masyarakat bisa teratasi dan tidak adanya kesenjangan antara kebijakan publik, dan komitmen dari program kerja.

\section{METODE PENELITIAN}

Metode penelitian yang digunakan ialah menggunakan penelitian kualitatif. Hal tersebut berangkat dari cara peneliti mendapatkan data, yakni dengan observasi lapangan (field research), wawancara, penggunaan dokumen, serta analisis intensif peneliti dengan narasumber. Jane Richie (Moleong, 2014:6) menjelaskan bahwa penelitian kualitatif ialah upaya untuk menyajikan dunia sosial, dan perspektifnya didalam dunia, dari segi konsep, perilaku, persepsi, dan persoalan tentang manusia yang diteliti. Dengan begitu, peneliti akan lebih mudah memahami dan menemukan setiap fenomena yang sampai sekarang belum banyak diketahui. 
Sifat penelitian yang digunakan dalam penelitian ini adalah sifat deskriptif. Hal ini berangkat dari cara peneliti mendapatkan data diantaranya pengumpulan kutipan-kutipan hasil wawancara, gambar, catatan lapangan, videotape, dokumen pribadi, serta pengumpulan informasi-informasi baik dari media cetak maupun elektronik.

\section{HASIL DAN PEMBAHASAN}

Permasalahan-permasalahan yang dihadapi organisasi atau lembaga tidak Permasalahan yang berdampak pada krisis akan berhenti begitu saja jika lembaga tidak melakukan langkah strategis pada saat tanda-tanda krisis muncul. Laurence Barton dalam abiding (2005: 11) mengemukakan bahwa krisis merupakan suatu peristiwa, suatu kejadian layak dikatakan sebagai krisis bila memenuhi tiga kriteria yaitu pertama, mengan- dung kejutan, kedua, krisis tersebut mengancam nilai-nilai penting dalam masyarakat, dan ketiga, membutuhkan keputusan segera.

Krisis merupakan peristiwa yang mengancam dengan tujuan terpenting untuk bertahan (Shrivastava \& Mitroff, dalam Ilfandy, 2017: 8). Usaha untuk bertahan saat ini adalah manajemen krisis yang baik dan terarah.

Manajemen krisis dilakukan sebagai bentuk upaya yang dilakukan Humas dalam mengahadapi krisis dengan pengambilan keputusankeputusan yang tepat, terus menganalisa, memantau, dan memberikan solusi, sehingga dapat mencegah meluasnya dampak negatif terhadap lembaga. Menurut Nova (2009: 53) sebaiknya, krisis tidak dianggap sebagai suatu petaka melainkan momentum untuk perbaikan. Oleh karena itu, sudut pandang dan memiliki sikap positif menjadi satu hal yang penting dalam manajemen krisis.

Berdasarkan warning time krisis terbagi dalam dua jenis (Nova, 2011: 100112), yaitu (1) Sudden Crisis, yang merupakan krisis yang terjadi secara mendadak karena gangguan di dalam bisnis perusahaan tanpa peringatan dan mungkin menghasilkan berita dan berdampak pada karyawan perusahaan, investor, pelanggan, suppliers atau masyarakat luas, pendapat perusahaan, laba bersih, juga reputasi perusahaan, (2) Smoldering Crisis; merupakan masalah bisnis yang tidak biasa terjadi di dalam perusahaan. Jika diketahui publik, krisis ini dapat menimbulkan pemberitaan negatif di media.

Krisis yang terjadi di Kabupaten Karawang tahun 2014 termasuk dalam jenis smoldering crisis. Investigasi dari badan pemerintahan atau KPK yang menetapkan Bupati Karawang, Ade Swara bersama istrinya, Nurlatifah sebagai tersangka pada hari Jumat tanggal 18 Juli 2014 merupakan OTT (Operasi Tangkap Tangan) yang mengejutkan masyarakat, terlebih penangkapan ini dilakukan pada pertengahan bulan Ramadhan. Krisis ini merupakan konsekuensi dari sebuah krisis darurat yang menimpa pejabat tertinggi di Kabupaten Karawang.

Tahapan-tahapan krisis yang dilakukan saat lembaga mengalami 
smoldering crisis adalah efektivitas yang menjadi fokus utama dalam tahapan pemulihan dan pencegahan, seperti:

- Humas melakukan identifikasi tetapi dilakukan dalam waktu cukup lama karena tidak ada sosok pemimpin yang bisa dimintai pertimbangan untuk mengambil suatu kebijakan, dimana pada saat itu Wakil Bupati sedang berada di Mekkah untuk melaksanakan ibadah umroh.

- Pemanggilan Ibu Cellica sebagai saksi oleh KPK, menimbulkan banyak persepsi negatif masyarakat. Maka, yang belum jelas kebenarannya harus dilakukan klarifikasi sehingga perlu sekali Humas melakukan pemahaman opini publik dengan membuat pemberitaan positif bahwa Ibu Cellica hanya dipanggil sebagai saksi.

- Isolasi krisis, dalam tahap ini hal yang dilakukan adalah komunikasi. Salah satu upaya menjalin komunikasi paling utama pada saat krisis adalah dengan pihak media massa yang dilakukan secara perlahan tetapi berdampak besar pada kredibilitas lembaga di hadapan media massa.

Humas politik merupakan proses manajemen dimana organisasi maupun humas bertujuan untuk politik; melalui komunikasi dan tindakan yang terarah, keduanya berusaha untuk mempengaruhi dan membangun, mempertahankan reputasi yang menguntungkan bagi publik, terutama untuk membantu serta mendukung misi sehingga tercapai tujuan yang diinginkan. Proses manajemen tersebut disebut dengan agenda building. Agenda building merupakan aspek dari rangkaian agenda (McComb, 2004), meskipun Cobb dan Elder (1971) pertama kali mempertanyakan istilah agenda building, karena beberapa masalah yang mendapat perhatian dari pembuat keputusan.

Botan dan Hazleton (2006, dalam Niken: 2012: 5) mendefinisikan bahwa agenda building adalah sebuah proses timbal balik dan kolektif yang dilakukan oleh public relations dalam relasinya dengan media massa. Telah banyak peneliti yang mengkaji mengenai proses agenda building ini, diantaranya Lang dan Lang (1981), Walters dan Gray (1996), Johnson et al (1996), dan Corbett dan Mori (1999, yang masing-masing dipaparkan bahwa agenda building terdiri atas empat fase, yaitu fase awal, fase 2 , fase 3 , dan fase akhir. 
Tabel I

Dinamika Proses Agenda Building

\begin{tabular}{|c|c|c|c|c|}
\hline & $\begin{array}{c}\text { Lang \& } \\
\text { Lang (1981) }\end{array}$ & $\begin{array}{c}\text { Walters } \\
\text { dan } \\
\text { Gray } \\
(1996)\end{array}$ & $\begin{array}{c}\text { Johnson } \\
\text { et al. } \\
\text { (1996) }\end{array}$ & $\begin{array}{l}\text { Corbett } \\
\& \text { Mori } \\
(1999)\end{array}$ \\
\hline $\begin{array}{l}\mathrm{Na} \\
\mathrm{ma}\end{array}$ & $\begin{array}{l}\text { Collective } \\
\text { and } \\
\text { Reciprocal }\end{array}$ & $\begin{array}{l}\text { Matching } \\
\text { 's Voters } \\
\text { Agenda }\end{array}$ & $\begin{array}{l}\text { Reciprocal } \\
\text { Agenda }\end{array}$ & $\begin{array}{l}\text { Circular } \\
\text { Relationsh } \\
\text { ip }\end{array}$ \\
\hline $\begin{array}{l}\text { Fas } \\
\text { e } \\
\text { Aw } \\
\text { al }\end{array}$ & $\begin{array}{l}\text { Berita di } \\
\text { media } \\
\text { mengedepa } \\
\text { nkan } \\
\text { kegiatan, } \\
\text { aktivitas, } \\
\text { kelompok, } \\
\text { dan } \\
\text { kepribadia } \\
\text { n }\end{array}$ & $\begin{array}{l}\text { Pemilih } \\
\text { menentu } \\
\text { kan isu } \\
\text { agenda } \\
\text { kandida } \\
\mathrm{t}\end{array}$ & $\begin{array}{l}\text { Realita } \\
\text { menentu } \\
\text { kan isu } \\
\text { dalam } \\
\text { proses } \\
\text { agenda- } \\
\text { building }\end{array}$ & $\begin{array}{l}\text { Isu } \\
\text { berkemba } \\
\text { ng di } \\
\text { masyarak } \\
\text { at }\end{array}$ \\
\hline $\begin{array}{l}\text { Fas } \\
\text { e } 2\end{array}$ & $\begin{array}{l}\text { Fokus } \\
\text { perhatian } \\
\text { sudah } \\
\text { dibingkai }\end{array}$ & $\begin{array}{l}\text { Pemilih } \\
\text { dan } \\
\text { kandida } \\
\mathrm{t} \\
\text { menentu } \\
\text { kan } \\
\text { agenda } \\
\text { untuk } \\
\text { pemberi } \\
\text { taan } \\
\text { media }\end{array}$ & $\begin{array}{l}\text { Pemberit } \\
\text { aan } \\
\text { mengenai } \\
\text { isu } \\
\text { tersebut } \\
\text { meningk } \\
\text { at }\end{array}$ & $\begin{array}{l}\text { Kelompo } \\
\mathrm{k} \\
\text { kepentin } \\
\text { gan } \\
\text { terlibat } \\
\text { dan } \\
\text { berperan } \\
\text { dalam isu } \\
\text { tersebut }\end{array}$ \\
\hline $\begin{array}{l}\text { Fas } \\
\text { e } 3\end{array}$ & $\begin{array}{l}\text { Objek } \\
\text { tersebut } \\
\text { dihubungk } \\
\text { an ke } \\
\text { kegiatan } \\
\text { atau symbol } \\
\text { sekunder } \\
\text { dan } \\
\text { menjadi } \\
\text { citra } \\
\text { berkelanjut } \\
\text { an }\end{array}$ & $\begin{array}{l}\text { Pemberi } \\
\text { taan di } \\
\text { media } \\
\text { mengatu } \\
\text { r agenda } \\
\text { dari } \\
\text { kandida } \\
t \text { dan } \\
\text { sektor } \\
\text { masyara } \\
\text { kat yang } \\
\text { berbeda }\end{array}$ & $\begin{array}{l}\text { Masyara } \\
\text { kat } \\
\text { memaha } \\
\text { mi } \\
\text { isyarat } \\
\text { penting } \\
\text { dari } \\
\text { realita } \\
\text { dan } \\
\text { pemberit } \\
\text { aan } \\
\text { media } \\
\text { massa }\end{array}$ & $\begin{array}{l}\text { Kelompo } \\
\mathrm{k} \\
\text { kepentin } \\
\text { gan } \\
\text { memenga } \\
\text { ruhi } \\
\text { media } \\
\text { dan } \\
\text { publik }\end{array}$ \\
\hline $\begin{array}{l}\text { Fas } \\
\text { e } \\
\text { Ak } \\
\text { hir }\end{array}$ & $\begin{array}{l}\text { Juru bicara } \\
\text { mulai } \\
\text { menarik } \\
\text { perhatian } \\
\text { media } \\
\text { massa }\end{array}$ & & $\begin{array}{l}\text { Opinion } \\
\text { leader } \\
\text { menunju } \\
\text { kkan } \\
\text { reaksi } \\
\text { pada } \\
\text { publik }\end{array}$ & $\begin{array}{l}\text { Pemberit } \\
\text { aan } \\
\text { media } \\
\text { massa } \\
\text { memenga } \\
\text { ruhi } \\
\text { publik, } \\
\text { kelompo } \\
\text { k } \\
\text { kepentin } \\
\text { gan, dan } \\
\text { politisi }\end{array}$ \\
\hline
\end{tabular}

Sumber :

Kutipan: Jurnal Abstraksi, Niken Kinanti Suryanto, "Kampanye Politik Viral dan Agenda Building
Media Massa" (2012)

Strategi agenda building bertujuan untuk mengetahui pola dan proses yang digunakan lembaga dalam melakukan relasi dengan media. Dalam kasus korupsi yang terjadi pada Kepala Daerah dan istri Kabupaten Karawang tahun 2014, peneliti menganalisis bagaimana strategi agenda building yang dilakukan lembaga terhadap media. Hal ini perlu dilakukan untuk mengetahui sejauh mana lembaga melibatkan media dalam membangun pemahaman opini publik dalam pemberitaan kasus ini dalam media.

Berdasarkan tabel III (halaman 53), peneliti menggunakan dinamika agenda building circular relationship, Corbett \& Mori (1999). Selain itu, peneliti juga menggunakan riset yang bersifat deskriptif. Artinya, peneliti memberikan gambaran mengenai situasi, latar sosial, atau hubungan.

Kehadiran media saat krisis sangat diperlukan untuk mengklarifikasi isu negatif yang berdampak buruk terhadap lembaga. Dari hasil penelitian yang dilakukan peneliti, dalam krisis yang terjadi di Kabupaten Karawang tahun 2014, fungsi Humas dalam hubungannya dengan media massa (Philip Lesley dalam Nova, 2011: 206) yaitu fungsi pasif dan pelayanan, fungsi setengah aktif, dan fungsi aktif, Humas Kabupaten Karawang tidak banyak melakukan hubungan dengan media massa. Artinya, fungsi Humas pasif dan pelayanan, bahwa pihak Humas hanya menanggapi permintaan pers dan tidak melakukan inisiatif tertentu, baik saat pra-krisis, saat krisis, maupun pasca krisis. 
Meskipun demikian, ada beberapa kegiatan media relations yang dilakukan oleh Humas kepada media yang sifatnya informal, baik untuk melakukan klarifikasi atau pun mengupdate kegiatan-kegiatan yang dilakukan lembaga pemerintahan Kabupaten Karawang seperti penyebaran pers, peliputan kegiatan, dan wawancara pers.

\section{KESIMPULAN}

Penelitian yang dilakukan terkait kasus korupsi Kepala Daerah Kabupaten Karawang, Bapak Ade Swara dan istri, Ibu Nurlatifah tahun 2014, cukup membawa pengaruh buruk terhadap persepsi, reputasi, citra, dan kredibilitas lembaga Kabupaten Karawang, yang berdampak pada krisis kepercayaan masyarakat terhadap lembaga Pemerintahan Daerah Kabupaten Karawang. Pemerintah Daerah Kabupaten Karawang berupaya memulihkan persepsi negatif dan mengembalikan kembali kepercayaan masyarakat terhadap lembaga.

Tahapan-tahapan krisis yang dilakukan saat lembaga mengalami smoldering crisis adalah efektivitas yang menjadi fokus utama dalam tahapan pemulihan dan pencegahan.

Pihak lembaga harus melakukan inisiatif untuk membangun relasi dengan pihak media. Relasi ini dapat dilakukan dengan perlahan tetapi berdampak besar pada persepsi positif publik karena memiliki kekuatan dalam penyebaran informasi kepada publik, terutama saat krisis.

\section{DAFTAR PUSTAKA}

Abiding Partao, zainal. 2005. Optimalisasi Fungsi Media Relations Untuk Keberhasilan Komunikasi Krisis. Jurnal Komunikologi Volume 2 No. 1.

Bungin, Burhan. 2006. Sosiologi Komunikasi - Teori, Paradigma, dan Diskursus Teknologi Komunikasi di Masyarakat. Jakarta: Kencana.

Ilfandy Imron, Ayub. 2017. Komunikasi Krisis. Yogyakarta: Deepublish.

Moleong, Lexy. 2014. Metodologi Penelitian Kualitatif. Bandung: PT Remaja Rosda Karya.

Nova, Firsan. 2011. Crisis Public Relations - Strategi PR Menghadapi Krisis, Mengelola Isu, Membangun Citra, dan Reputasi Perusahaan. Jakarta: PT RajaGrafindo Persada.

Nova, Firsan. 2014. PR War. Jakarta: Gramedia Widiasarana. Pearson, Christine. 2008. Crisis Management. Singapore: Far East Square.

Nova, Firsan. 2017. Crisis Public Relations. Jakarta: Grasindo.

Suryanto, Niken Kinanti. 2012. Kampanye Politik Viral dan Proses Agenda Building Media Massa Online (Studi 